\title{
ORIENTALISTYKA LWOWSKA I KRAKOWSKA - DWA OŚRODKI NAUKOWE ORAZ ICH WZAJEMNE POWIAZZANIA
}

\author{
Karolina Wanda Olszowska \\ Uniwersytet Jagielloński w Krakowie
}

\author{
ABSTRACT \\ ORIENTAL STUDIES IN LVIV AND CRACOW: TWO ACADEMIC \\ CENTERS AND THEIR RELATIONSHIP
}

Over the centuries, the interest in languages of the Middle and Far East varied in dimensions. At the beginning, the oriental languages were taught at the Faculty of Theology, with the aim of improving the understanding of the Holy Bible. It was only in the $20^{\text {th }}$ century that the role of the oriental studies began to be fully appreciated as a separate area of study, not affiliated with theology. A bit earlier, the so-called "Dragoman school" was founded, where the oriental languages were taught for diplomatic and translation needs. After the recovery of independence by Poland, the Chairs of Oriental Studies were founded in Cracow, Lviv and Warsaw. In this paper I present the development of oriental studies in Cracow and Lviv. I pay a particular attention to the relationship between those two universities and to people associated with both these academic centers. I compare the development of the Oriental Studies in Lviv and Cracow up to 1939 and emphasize the contribution of the orientalists from Lviv to the creation of the Oriental Studies in Cracow.

Key words: oriental studies, University of Cracow, University of Lviv.

Słowa kluczowe: orientalistyka, Uniwersytet Jagielloński, Uniwersytet Lwowski.

Współcześnie, gdy orientalistyka cieszy się coraz większym zainteresowaniem, a w Polsce o prymat konkurują ze sobą ośrodki krakowski, warszawski i poznański, trudno sobie wyobrazić, że do XIX wieku języki orientalne nauczane były głównie w związku z teologią. W międzywojniu działały w Polsce trzy ośrodki: w Krakowie, we Lwowie i w Warszawie. Dwa pierwsze powstały wcześniej i tworzone były przez wybitnych specjalistów, którzy pobierali nauki w czołowych europejskich ośrodkach naukowych. Wielu z nich związanych było z obydwoma tymi ośrodkami. Wydawać by się mogło, że we Lwowie prężniej rozwijały się nauki związane z Dalekim 
Wschodem, w Krakowie większy nacisk położony był na Bliski Wschód, ale w rzeczywistości częstokroć było to zasługą pojedynczych, wybitnych osób. Rywalizacja między tymi dwoma ośrodkami orientalistyki zakończyła się wraz z II wojną światową, kiedy to uniwersytet we Lwowie przestał być polską uczelnią, a jego orientaliści-wykładowcy zasilili krakowską lub warszawską kadrę.

\section{WPROWADZENIE}

Nawiązanie relacji polsko-osmańskich datuje się na 1414 rok, kiedy to do imperium osmańskiego dotarli Grzegorz Ormianin i Jakub Skarbek z Góry, przedstawiciele Królestwa Polskiego' ${ }^{1}$. W państwie Jagiellonów brakowało profesjonalnych tłumaczy języka osmańskiego, dlatego do tego celu wykorzystywano lwowskich mieszczan pochodzenia tatarskiego i ormiańskiego. To właśnie Ormianie byli pierwszymi popularyzatorami sztuki islamskiej w Rzeczpospolitej². Początek naukowego zainteresowania orientalistyką w Europie datuje się na XV wiek, kiedy to na uniwersytetach Starego Kontynentu zaczęły się pojawiać studia hebraistyczne ${ }^{3}$. W następnym stuleciu język hebrajski wykładany był prawie na wszystkich uniwersytetach europejskich, ponieważ uważano, że prawdziwy humanista powinien znać grekę, łacinę i właśnie hebrajski. W tym okresie znajomość języków orientalnych wiązała się w dużym stopniu z teologią i z możliwością poznania Pisma Świętego, nie zaś z badaniami orientalistycznymi we współczesnym rozumieniu. W 1754 roku w Wiedniu została założona Akademia Orientalna, gdzie kształcono w tym okresie głównie przyszłych dyplomatów ${ }^{4}$.

Stanisław August Poniatowski zdawał sobie sprawę z potrzeby wykształcenia profesjonalnych tłumaczy. Zabiegał o utworzenie w Konstantynopolu Szkoły Dragomanów (tłumaczy), która działała w latach 1766-17935. W pierwszym roku istnienia szkoły studiowali tam czterej studenci, którzy zobowiązali się po zakończeniu edukacji przejść na usługi Jego Królewskiej Mości'.

1 J. Długosz, Roczniki czyli kroniki sławnego Królestwa Polskiego, t. VII, ks. XI, Warszawa 2009, s. $46-48$.

2 T. Mańkowski, Orient w polskiej kulturze artystycznej, Wrocław 1959, s. 49.

3 W. Zajączkowski, Z dziejów orientalistyki na Uniwersytecie Jagiellońskim [w:] Wydziat Filologiczny Uniwersytetu Jagiellońskiego. Historia katedr, red. W. Taszycki, A. Zaręba, Kraków 1964, s. 368.

4 J. Reychman, Historia Turcji, Wrocław 1973, s. 171.

5 S.L. Krowicki, Polska Szkoła Języków Orientalnych w Stambule, „Przegląd Historyczno-Oświatowy" 2011, nr 3-4, s. 34.

6 J. Reychman, Polska Szkoła Orjentalna w Stambule za Stanisława Augusta, „Wschód. Kwartalnik Poświęcony Sprawom Wschodu" 1930, nr 1, s. 7. 
Tradycję badań orientalistycznych we Lwowie zapoczątkował w XVII wieku mi-

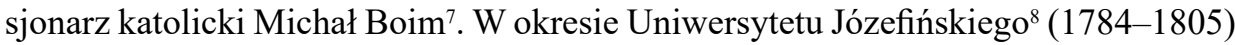
badania orientalistyczne prowadzono na Wydziale Teologicznym, ale aż do początku $\mathrm{XX}$ wieku we Lwowie nie było regularnych studiów orientalistycznych' ${ }^{9}$ Co się tyczy zaś Krakowa, pierwszym profesorem (lektorem) hebrajskiego na Uniwersytecie Krakowskim został Leonard Dawid, który wykładał tam od około 1529 roku $^{10}$. Na początku XVII wieku prawie całkowicie zanikła znajomość hebrajskiego na krakowskiej uczelni. Przez XVIII stulecie nauczano języków orientalnych, głównie na Wydziale Teologicznym, aż do początków XX wieku nie prowadzono regularnych orientalistycznych studiów naukowych ${ }^{11}$.

\section{XIX-WIECZNA ORIENTALISTYKA UKIERUNKOWANA NA ZNAJOMOŚĆ STAREGO TESTAMENTU}

XIX wiek przyniósł renesans zainteresowania naukami orientalistycznymi, ale sytuacja na uniwersytetach we Lwowie i w Krakowie w tym czasie się skomplikowała. W 1803 roku nastąpiło połączenie w jedną prowincję Galicji Wschodniej i Zachodniej ${ }^{12}$. Odżyły wówczas plany utworzenia jednej, zespolonej uczelni dla całej prowincji. W 1805 roku na polecenie cesarza Franciszka I wcielono uniwersytet lwowski do Szkoły Głównej Krakowskiej (taką nazwę nosiła w tym okresie krakowska uczelnia) ${ }^{13}$. W toku rozbudowy Wydziału Teologicznego w 1805 roku powstała katedra języków wschodnich: hebrajskiego, arabskiego, syryjskiego, chaldejskiego ${ }^{14}$. W roku akademickim 1808/1809 wykładowcą języków orientalnych był benedyktyn o. Marcin Altegger ${ }^{15}$. W 1809 roku Kraków ponownie znalazł się poza granicami

7 B. Richter, Michat Boim 1612-1659, „Rocznik Orientalistyczny” 1926, t. IV, s. 15-20.

8 Po kasacie zakonu jezuitów w 1773 r. Akademia Lwowska przestała funkcjonować. W 1784 r. cesarz Józef II podpisał dyplom fundacji Uniwersytetu we Lwowie (miał on się składać z czterech wydziałów: prawa, medycyny, teologii i filozofii). W 1803 r. Galicję Zachodnią włączono do Królestwa Galicji i Lodomerii. Wielokrotnie podnoszono sprawę przekształcenia lwowskiej wszechnicy w szkołę średnią i wzmocnienia tym sposobem uniwersytetu w Krakowie. Uniwersytet Józefiński przestał istnieć w 1805 r., kiedy to zgodnie z dekretem cesarza Franciszka I przeniesiono uniwersytet do Krakowa. Zob. A. Redzik, Uniwersytet Józefiński 1784-1805 [w:] Academia Militans. Uniwersytet Jana Kazimierza we Lwowie, red. A. Redzik, Kraków 2015, s. 82-90.

9 Ł.T. Sroka, Wydziat Humanistyczny [w:] Academia Militans..., s. 599.

10 H. Baryc z, Historja Uniwersytetu Jagiellońskiego w epoce humanizmu, Kraków 1935, s. 88-89.

11 Ł.T. Sroka, op. cit., s. 599.

12 W latach 1795-1797 do tzw. starej Galicji dołączono nową Galicję Zachodnią. W 1803 r. obie prowincje połączono w jedną i utrzymano dla nich nazwę Królestwo Galicji i Lodomerii z Księstwem Oświęcimskim i Zatorskim. Zob. A. Chwalba, Historia Polski 1795-1918, Kraków 2000, s. 189.

13 A.K. Banach, Czasy zaborów. Uniwersytet Jagielloński w latach 1795-1918 [w:] Dzieje Uniwersytetu Jagiellońskiego, red. K. Stopka, A.K. B anach, J. Dybiec, Kraków 2000, s. 88.

14 W. Zajączkowski, op. cit., s. 371.

15 Ibidem. 
austriackimi, od 14 października 1809 roku stał się częścią Księstwa Warszawskiego. Wtedy też profesorowie lwowscy powrócili na dawne stanowiska do Lwowa ${ }^{16}$. Uniwersytet we Lwowie został ponownie ufundowany przez cesarza Franciszka I w $1817 \mathrm{roku}^{17}$.

2 czerwca 1815 roku Rada Wydziału Teologicznego UJ uchwaliła wniosek o utworzenie katedry języków wschodnich i archeologii biblijnej oraz filologii i egzegezy Starego Testamentu z językiem hebrajskim, chaldejskim i syryjskim. Przez lata wykładało tam wielu biblistów-orientalistów, między innymi ksiądz Piotr Pękalski czy ksiądz Feliks Sosnowski. Zainteresowanie wykładami z języków Wschodu było na tyle duże, że w latach 30. XIX wieku na zajęcia przychodzili nie tylko studenci Wydziału Teologicznego, ale również wolni słuchacze $\mathrm{z}$ innych wydziałów ${ }^{18}$. Podczas ćwiczeń z języka arabskiego przekładano także sury Koranu na łacinę ${ }^{19}$. Lektoraty $\mathrm{z}$ języków orientalnych takich jak arabski i hebrajski były prowadzone na Wydziale Teologicznym przez cały XIX wiek ${ }^{20}$.

Dzięki staraniom kierownika Biblioteki Jagiellońskiej, profesora Jerzego Samuela Bandtkiego, w 1818 roku utworzono na Wydziale Filozoficznym UJ katedrę języków wschodnich i literatury orientalnej. Objął ją profesor Wilhelm Münnich, który nauczał języków hebrajskiego, chaldejskiego, syryjskiego, arabskiego, perskiego, tureckiego, etiopskiego i samarytańskiego ${ }^{21}$. Po opuszczeniu Krakowa przez profesora Münnicha, co stało się w 1826 roku, podjęto uchwałę o likwidacji katedry. Pomimo starań Joachima Lelewela, który proponował, aby katedrę języków wschodnich objął doktor Ignacy Pietraszewski z Uniwersytetu w Berlinie, projekt ten nie został zrealizowany ${ }^{22}$.

$\mathrm{Na}$ uniwersytecie we Lwowie pierwsza katedra orientalistyczna powstała w 1916 roku. Katedra nadzwyczajna języków semickich i historii starożytnego semickiego Wschodu została utworzona za sprawą awansu Mojżesza Schorra, wybitnego asyriologa, ze stanowiska docenta na profesora ${ }^{23}$. W 1917 roku Andrzej Gawroński rozpoczął pracę w katedrze językoznawstwa indoeuropejskiego porównawczego i filologii indyjskiej.

16 Z. Skubała-Tokarska, Z. Tokarski, Uniwersytety w Polsce. Rys historyczny, Warszawa 1972, s. 126.

17 Ibidem, s. 126.

$18 \mathrm{~K}$. Michalewska, Z dziejów nauczenia orientalistyki na Uniwersytecie Jagiellońskim w latach 1818-1836 [w:] Szkice z dziejów polskiej orientalistyki, red. M. Lewicki, Wrocław 1966, s. 118.

19 Personal-Stand und Ordnung der Vorlesungen an der k. k. Jagellonischen Universität zu Krakau im Sommer-Semester des Schuljahres 1859, Krakau 1859, [b.n.s.].

20 Personal-Stand und Ordnung der Vorlesungen an der k. k. Jagellonischen Universität zu Krakau im Sommer-Semester des Schuljahres 1860, Krakau 1860, [b.n.s.].

21 W. Zajączkowski, op. cit., s. 375.

22 K. Maciuszak, Z historii orientalistyki na Uniwersytecie Jagiellońskim, „Alma Mater” 2009/2010, nr 120-121, s. 138.

${ }_{23}$ Archiwum Nauki Polskiej Akademii Umiejętności i Polskiej Akademii Nauk w Krakowie [dalej: AN PAU/PAN Kr], Spuścizna Ireny i Mariana Lewickich - K III-7, 13 [dalej: K III-7, 13], M. Lewicki, Historia orientalistyki w Polsce odrodzonej, [b.d.], k. 144. 
Andrzej Gawroński - wybitny językoznawca znający co najmniej 60 języków i narzeczy - związany był zarówno z Uniwersytetem we Lwowie, jak i z ośrodkiem w Krakowie ${ }^{24}$. Studia ukończył we Lwowie oraz w Lipsku, gdzie też obronił doktorat. Habilitację i profesurę uzyskał zaś na UJ, odpowiednio w 1912 i 1916 roku. Habilitował się z zakresu filologii indyjskiej na podstawie pracy Am Rande des Mrcchakațika. Jako propozycje wykładu habilitacyjnego, zgodnie z panującym wówczas zwyczajem, podał: „» Transcendencyjny « charakter Indusów jako tło stosunków człowieka do świata zwierzęcego w literaturze klasycznej sanskryckiej”; „Początek i rozwój dramatu indyjskiego w świetle badań ostatniego dwunastolecia” oraz „Stereotypowość klasycznej literatury sanskryckiej"25. Pracując w Krakowie, Andrzej Gawroński objął wakującą od 1909 roku Katedrę Sanskrytu. Warto tutaj nadmienić, że katedra sanskrytu została utworzona na krakowskiej wszechnicy w 1893 roku, do 1909 roku wykładał na niej profesor Leon Mańkowski, a od 1913 roku Gawroński, przez trzy lata wykłady nie były prowadzone ${ }^{26}$. Po śmierci profesora Gustawa Blatta w 1916 roku Gawroński udał się w następnym roku do Lwowa, aby podjąć tam pracę. Jeszcze podczas pobytu w Krakowie w 1915 roku stworzył wraz z Janem Grzegorzewskim „Rocznik Oryentalistyczny”27. Profesor Gawroński chciał powołać do życia we Lwowie katedrę orientalistyki na światowym poziomie. Udało mu się uruchomić trzy katedry: arabistyki, mongolistyki i sanskrytu, do objęcia których zapraszał naukowców światowej sławy, między innymi profesora Stefana Stasiaka, profesora Zygmunta Smogorzewskiego i profesora Władysława Kotwicza ${ }^{28}$.

\section{ORIENTALISTYKA W POLSCE ODRODZONEJ - LWÓW}

Formalnie Instytut Orientalistyczny we Lwowie został założony w 1921 roku. W jego skład weszły istniejące już wcześniej katedra nadzwyczajna języków semickich i historii starożytnego Wschodu oraz katedra językoznawstwa porównawczego (obsadzona przez prof. Andrzeja Gawrońskiego). Profesor Władysław Kotwicz objął katedrę Dalekiego Wschodu w 1924 roku. Prowadził w tym czasie zajęcia z filologii mongolskiej, a od 1931 roku również z filologii mandżurskiej i dziejów ludów koczowniczych Azji Środkowej oraz seminarium i wykłady z filologii

24 E. Słuszkiewicz, Wspomnienie o Andrzeju Gawrońskim w dziesięciolecie zgonu, „Rocznik Oryentalistyczny" 1936, t. XII, s. 2.

${ }^{25}$ Archiwum Uniwersytetu Jagiellońskiego [dalej: AUJ], Wydział Filozoficzny - Teczki akt habilitacyjnych - WF II 121 [dalej: WF II 121] - Gawroński Andrzej, Informacja od A. Gawrońskiego o tytule rozprawy habilitacyjnej i tematach wykładu, Zakopane 1912.

${ }_{26}$ AN PAU/PAN Kr, K III-7, 13, M. Lewicki, Historia orientalistyki w Polsce odrodzonej, [b.d.], k. 146.

27 J. Fedirko, Fenomenalny multilingwista. Profesor Andrzej Gawroński (1885-1927), „Alma Mater" 2008, nr 2 (100), s. 76.

28 Ibidem. 
anatolijsko-tureckiej ${ }^{29}$. Marian Lewicki w maszynopisie artykułu Historia orientalistyki w Polsce odrodzonej wspomina, że Władysław Kotwicz uważał, że rozbicie studiów orientalistycznych na różne ośrodki działa na ich niekorzyść, i był zwolennikiem ich centralizacji ${ }^{30}$. Podczas dyskusji o potrzebie stworzenia Instytutu Orientalistyki we lwowskiej wszechnicy znaczącą rolę odegrali filolodzy klasyczni, którzy wydali opinię, że ich dziedzina nauki jest również ściśle powiązana z dziejami i kulturą Wschodu, podkreślając szczególnie potrzebę stworzenia w przyszłości katedry egiptologicznej ${ }^{31}$.

Katedra Językoznawstwa Porównawczego na Uniwersytecie Jana Kazimierza w 1925 roku została podzielona na Katedrę Językoznawstwa Indoeuropejskiego oraz Katedrę Filologii Indyjskiej. Utworzono również dwie inne: Katedrę Filologii Dalekiego Wschodu i Katedrę Filologii Wschodu Muzułmańskiego ${ }^{32}$. Bardzo ważną lwowską inicjatywą, która później przybrała wymiar ogólnopolski, było założenie w 1922 roku we Lwowie Polskiego Towarzystwa Orientalistycznego. Po II wojnie światowej jego siedziba została przeniesiona do Krakowa, a następnie - w 1953 roku - do Warszawy ${ }^{33}$. Uniwersytet Jana Kazimierza w dwudziestoleciu międzywojennym mógł się pochwalić prężnie działającą iranistyką. Do badań nad kulturą Iranu wykorzystywano problematykę indologiczną ${ }^{34}$. Na lwowskiej orientalistyce rozwijały się również sinologia i japonistyka, głównie dzięki wybitnemu specjaliście w tej dziedzinie Bogdanowi Richterowi. Niestety po jego przeniesieniu się do Warszawy pod koniec lat 20. XX wieku nie miał kto go zastąpić i ostatecznie Katedra Sinologii we Lwowie została zlikwidowana (w 1928 r.) ) $^{35}$. Dużą stratą dla orientalistyki lwowskiej było przeniesienie się profesora Mojżesza Schorra, wspomnianego już historyka, semitologa, znawcy prawa babilońskiego, do Warszawy. W rezultacie przestała działać katedra języków semickich. W 1927 roku, w ramach swoistej rekompensaty, Wydział Humanistyczny uruchomił wykłady zlecone z języka aramejskiego i hebrajskiego ${ }^{36}$. Uzupełnieniem studiów były lektoraty, między innymi z tureckiego, prowadzony przez Sadyka-Beja Agabekzadega, Turka z Azerbejdżanu, czy też z języka arabskiego, prowadzony najpierw przez Harbiego ben Hagz Kuwejdira, Araba z północnej Afryki, a później przez Tadeusza Lewickiego, oraz lektorat z sanskrytu prowadzony przez Eugeniusza Słuszkiewicza ${ }^{37}$. Profesor Michał Lewicki w swoim artykule opisującym historię orientalistyki w Polsce stwierdził, że lektoraty kiero-

29 AN PAU/PAN Kr, K III-7, 11, Marian Lewicki, Artykuł o Władysławie Kotwiczu..., k. 23.

30 AN PAU/PAK Kr, K III-7, 13; M. Lewicki, Historia orientalistyki w Polsce odrodzonej, [b.d.], k. 4.

31 Ibidem, k. 143-144.

32 Ł.T. Sroka, op. cit., s. 601.

33 AN PAU/PAN Kr, K III-7, 11; M. Lewicki, Artykuł o Władysławie Kotwiczu..., k. 23; Polskie Towarzystwo Orientalistyczne. Historia i cele, http://pto.orient.uw.edu.pl/ [dostęp: 10.08.2017].

34 J. Sierakowska-Dyndo, S. Surdykowska, Iranistyka [w:] 75 lat Instytutu Orientalistyki Uniwersytetu Warszawskiego, red. M. Popke, Warszawa 2007, s. 102-103.

35 AN PAU/PAN Kr, K III-7, 13; M. Lewicki, Historia orientalistyki w Polsce odrodzonej, [b.d.], k. 146.

36 Ibidem.

37 Ibidem. 
wane przez lektorów, a nie przez profesorów były w tamtym czasie nowym rozwiązaniem $^{38}$. Na drodze do realizacji bardzo ambitnych planów twórcy orientalistyki lwowskiej napotykali na przeszkody natury finansowej. Instytut Orientalistyki składał się jedynie z trzech zakładów, podczas gdy zainteresowania badawcze pracowników obejmowały cały Wschód. Instytut Orientalistyki oraz Wydział Teologiczny wniosły ogromny wkład w rozwój polskiej orientalistyki.

\section{NARODZINY KRAKOWSKIEJ ORIENTALISTYKI}

Na UJ w odrodzonej Polsce, obok katedry sanskrytu założonej w 1893 roku, powstało w 1919 roku seminarium filologii orientalnej, gdzie wykładał profesor Tadeusz Kowalski. Już wtedy podkreślał on potrzebę rozwijania w Polsce studiów orientalistycznych ${ }^{39}$. Chciał stworzyć w Krakowie seminarium języków wschodnioazjatyckich. W 1921 roku wpłynął do Ministerstwa Wyznań Religijnych i Oświecenia Publicznego wniosek o powołanie na seminarium o takiej właśnie nazwie wybitnego orientalisty Władysława Kotwicza ${ }^{40}$. Wcześniej profesor Kotwicz otrzymał również propozycję objęcia utworzonej dla niego Katedry Filologii Dalekiego Wschodu i uczestniczenia w pracach organizacyjnych orientalistyki polskiej na Uniwersytecie Jana Kazimierza we Lwowie ${ }^{41}$. Wybitny petersburski profesor przyjął drugą z tych propozycji.

Tadeusz Kowalski, twórca krakowskiej orientalistyki, studiował w Wiedniu i tam też obronił doktorat, ale habilitację uzyskał już na UJ na podstawie pracy $D e r D i$ van des Kais ibn al Hatun ${ }^{42}$. Po uzyskaniu nominacji na stanowisko profesora nadzwyczajnego objął seminarium filologii orientalnej, która została utworzona 1 lipca 1919 roku, wraz z wydaniem dekretu podpisanego przez naczelnika państwa Józefa Piłsudskiego ${ }^{43}$. Kowalski prowadził wykłady w zakresie trzech filologii Bliskiego Wschodu: tureckiej, arabskiej i perskiej, z uwzględnieniem nie tylko języka, ale również kultury i literatury. Szczególnie duży wkład miał w rozwój turkologii - można

38 AN PAU/PAN Kr, K III-7, 11; M. Lewicki, Artykuł o Władysławie Kotwiczu..., [b.d.], k. 19.

39 AN PAU/PAN Kr, K III-7, 13; M. Lewicki, Historia orientalistyki w Polsce odrodzonej, [b.d.], k. 4.

40 Władysław Kotwicz ukończył gimnazjum w Wilnie, w 1891 r. podjął studia na Wydziale Języków Wschodnich Uniwersytetu w Petersburgu. Zajmował się Dalekim Wschodem. W 1917 r. został docentem etatowym, a w 1923 r. profesorem. Piastował stanowisko dyrektora Piotrogrodzkiego Instytutu Żywych Języków Wschodnich. W 1923 r. wyjechał do Polski, gdzie od 1924 r. wykładał na Uniwersytecie Jana Kazimierza we Lwowie. Był wybitnym ałtaistą, znał m.in. język mongolski klasyczny, mandżurski, chałchaski, kałmucki, języki i dialekty tunguskie, interesował się również zagadnieniami związanymi z historią i kulturą ludów stepowych Azji Środkowej. Pozostawił po sobie wiele cennych prac. Zob. S. Kałużyński, Władysław Kotwicz w stulecie urodzin, „Przegląd Orientalistyczny” 1972, nr 2 (82), s. 103-114.

${ }_{41}$ AN PAU/PAN Kr, K III-7, 11, Marian Lewicki, Artykuł o Władysławie Kotwiczu..., [b.d.], k. 19.

42 AUJ, WF II 121 - Ocena pracy habilitacyjnej Tadeusza Kowalskiego, Kraków, [b.d.].

43 K. Maciuszak, op. cit., s. 138. 
go nawet nazwać twórcą tej dziedziny w naszym kraju ${ }^{44}$. Andrzej Zaborski podkreśla, że Tadeusz Kowalski był też twórcą polskiej arabistyki, iranistyki i islamistyki ${ }^{45}$. W 1921 roku powierzono mu kierowanie pracami Seminarium Filologii Orientalnej, nowej jednostki dydaktyczno-badawczej ${ }^{46}$.

Tadeusz Kowalski, wykształcony na Uniwersytecie Wiedeńskim, zajął się badaniami nad turecką dialektologią i literaturą ludową już w 1916 roku, kiedy to za zgodą władz austriackich pełnił w szpitalu funkcję tłumacza rannych tureckich żołnierzy ${ }^{47}$. W spisie wykładów na semestr letni 1916/1917 znajdują się już zajęcia z gramatyki arabskiej, czytania tekstów nowoperskich i praktycznego kursu języka tureckiego (osmańskiego ${ }^{48}$. Kowalski w swoich badaniach zajmował się także innymi językami turkijskimi, w szczególności językiem Karaimów polskich ${ }^{49}$. W 1922 roku uruchomiono lektorat $\mathrm{z}$ języka tureckiego prowadzony przez Feriduna Iskendera.

Od czasów, gdy język i literaturę perską wykładał Wilhelm Münnich, przez blisko 100 lat nie było studiów iranistycznych na UJ. Tadeusz Kowalski ma niemałe zasługi również dla iranistyki krakowskiej. W swoich badaniach zajmował się językiem nowoperskim i perską literaturą klasyczną. Zwracał uwagę na to zagadnienie jako na część kultury islamu, nie koncentrując się zbytnio na zagadnieniach związanych $z$ kulturą i literaturą przedmuzułmańską czy z językami staro- i średnioirańskim. Brakowało również lektoratów z irańskimi lektorami ${ }^{50}$.

Zakład Iranistyki został założony przez twórcę nowoczesnej iranistyki, profesora Franciszka Machalskiego. To dzięki niemu studia iranistyczne w Polsce uzyskały status odrębnej dyscypliny nauki. Ten wybitny iranista ukończył orientalistykę i polonistykę na Uniwersytecie Jana Kazimierza. Na tej samej uczelni uzyskał stopień doktora filozofii w zakresie filologii arabskiej i perskiej. W latach 1929-1931 był zastępcą asystenta przy zakładzie Bliskiego Wschodu na swojej Alma Mater ${ }^{51}$. Profesor Machalski został aresztowany przez NKWD w 1941 roku i wywieziony do Kazachstanu $^{52}$. Ze Związku Socjalistycznych Republik Radzieckich wyszedł z armią generała Władysława Andersa. Gdy doszedł wraz z nią do Iranu, zaangażował się w działanie Towarzystwa Studiów Iranistycznych. Pobyt w tym kraju przyczynił się do znacznego poszerzenia wiedzy Machalskiego, głównie o zagadnienia związane ze

44 W. Zajączkowski, op. cit., s. 378.

45 A. Zaborski, Tadeusz Kowalski-pierwszy i ostatni nowoczesny orientalista polski [w:] Tadeusz Kowalski 1889-1948. Materiały z Posiedzenia Naukowego PAU w dniu 19 czerwca 1998 r., red. R. Majkowska, Kraków 1999, s. 9.

46 Sktad uniwersytetu rok szkolny 1921/1922, Kraków 1922, [b.n.s.].

47 P. Nykiel, Türk atları Vistül nehrinden su içtiğinde / Kiedy Turcy napoja konie $w$ Wiśle / When the Turks Water Their Horses in Vistula, Warszawa 2016, s. 55-57.

48 Spis wyktadów w pótroczu letnem rok szkolny 1916/1917, Kraków 1917, [b.n.s.].

49 E. Siemieniec-Gołaś, Krakowska turkologia - historia, teraźniejszość i perspektywy [w:] Orientalia Commemoriativa, red. L. Sudyk, Kraków 2011, s. 49.

50 A. Krasnowolska, Iranistyka krakowska i jej twórcy [w:] Orientalia Commemoriativa..., s. 35.

51 AUJ, Wydział Filologiczny - Wnioski o nadanie tytułu profesora 1954-1972, cz. II - WFlg 24 [dalej: WFlg 24], Życiorys własny Franciszka Machalskiego.

52 A. Krasnowolska, Machalski Franciszek [w:] Encyclopaedia Iranica, http://www.iranicaonline.org/articles/machalski-franciszek [dostęp: 10.08.2017]. 
współczesnym mu Iranem i językiem perskim. Lata 1946-1947 spędził jako polski uchodźca w Libanie, gdzie dalej czynnie zajmował się iranistyką. Jego rozprawa habilitacyjna dotyczyła historii powieści perskiej doby współczesnej ${ }^{53}$. Po repatriacji do Polski w 1951 roku związał się z Katedrą Filologii Orientalnej UJ, prowadząc wykłady między innymi z filologii nowoperskiej.

Profesor Kowalski na wspomnianym wyżej Seminarium Filologii Orientalnej wykładał również arabistykę. Po jego śmierci w 1948 roku zastąpił go profesor Tadeusz Lewicki. Był to arabista i mediewista, studiował prawo na uniwersytecie we Lwowie, później wyjechał do Paryża i Algierii, aby po powrocie do Lwowa pod kierunkiem wybitnych specjalistów - Zygmunta Smogorzewskiego i Aleksego Klawka - podjąć studia orientalistyczne na lwowskiej uczelni ${ }^{54}$. Stopień doktora uzyskał we Lwowie. Po powrocie z kolejnego pobytu w Paryżu objął katedrę historii starożytnej właśnie we Lwowie. Po II wojnie światowej Tadeusz Lewicki przeniósł się do Krakowa, gdzie pracował na UJ. Naukowo zajmował się między innymi badaniem arabskich źródeł do dziejów Słowiańszczyzny oraz sektą ibadytów.

Profesor Leon Mańkowski objął otwartą w 1893 roku katedrę sanskrytu, zmarł w 1906 roku i od tego czasu trwał wakat na tej katedrze. Starał się o nią wybitny indolog, profesor Andrzej Gawroński, który rozpoczął wykłady na UJ w 1913 roku, ale nie przeprowadził ich do końca, ponieważ z powodu ataku gruźlicy wyjechał do Turolu. W 1916 roku Gawroński został profesorem nadzwyczajnym i objął katedrę sanskrytu. Rok później opuścił Kraków, aby przenieść się do Lwowa. Katedra nie była odsadzona aż do 1927 roku. Od wyjazdu profesora Gawrońskiego profesor Tadeusz Kowalski i profesor Jan Michał Rozwadowski, językoznawca, zabiegali o ponowne obsadzenie seminarium sanskrytu i filologii indyjskiej. Starania te powiodły się i w 1927 roku kierownictwo nad nim przejęła profesor Helena Willman-Grabowska ${ }^{55}$. Część bliskowschodnia Instytutu Orientalistyki była w Krakowie znacznie lepiej obsadzona. Część dalekowschodnią stanowiły z kolei wykłady indologiczne oraz lektorat z języka japońskiego prowadzony przez Amerykanina, doktora Denzela R. Carra, który przebywał w Polsce na stypendium Fundacji Kościuszkowskiej. Inny lektorat z języka dalekowschodniego (sinologii) prowadził doktor Witold Jabłoński ${ }^{56}$. Wspomniane lektoraty nie funkcjonowały jednak przez całe dwudziestolecie międzywojenne, a jedynie przez kilka lat - od 1930 do 1933 roku $^{57}$.

53 AUJ, WFlg 24, Życiorys własny Franciszka Machalskiego.

54 W. Kubiak, Profesor Tadeusz Lewicki: January 28, 1906-November 22, 1992, „Rocznik Orientalistyczny" 1997, t. II, s. 7-10.

55 Helena Willman-Grabowska uważana jest za pierwszą polską indianistkę. Uzyskała doktorat na paryskiej Sorbonie. Przez siedem lat wykładała tam sanskryt oraz język kanonu buddyjskiego - pali. W Krakowie objęła Katedrę Sanskrytu i Filologii Indyjskiej w 1928 r. W tym samym roku uzyskała profesurę nadzwyczajną, a na profesurę zwyczajną musiała czekać kolejne pięć lat. Zob. R. Czekalska, Helena Willman-Grabowska [w:] Uniwersytet Jagielloński. Złota Księga Wydziału Filologicznego, red. J. Michalik, W. Walecki, Kraków 2000, s. 224-226.

56 AN PAU/PAN w Kr, K III-7, 13, M. Lewicki, Historia orientalistyki w Polsce odrodzonej, [b.d.], k. 147.

57 K. Maciuszak, op. cit., s. 142. 
Studenci mieli możliwość uczestniczenia również w innych wykładach. W latach 1925-1939 prowadzone były wykład zlecony z języka koptyjskiego oraz wykład z zakresu cywilizacji sumero-akkadyjskiej. Obydwa w języku francuskim prowadził ksiądz Pierre David ${ }^{58}$. W 1937 roku inny wykład zlecony, tym razem z języka akadyjskiego, prowadził ksiądz docent Józef Jelito. W latach 1926-1939 prowadzony był także lektorat z języka hebrajskiego ${ }^{59}$.

\section{CENTRALIZACJA CZY DECENTRALIZACJA?}

17 września 1927 roku Ministerstwo Wyznań Religijnych i Oświecenia Publicznego wydało rozporządzenie normujące program studiów magisterskich z filologii, $\mathrm{w}$ tym orientalistyki ${ }^{60}$. Zgodnie z nim studia trwać miały cztery lata, podczas których student powinien się zapoznać z gramatyką i tekstami jednego wybranego języka wschodniego z jednym lub dwoma językami dodatkowymi. Egzaminy i praca magisterska miały wykazać znajomość języka oraz źródeł. Na egzaminach z języków żywych wymagana była ich znajomość w mowie i piśmie. Oprócz języka studentów obowiązywały również kursy i egzaminy z zakresu historii, etnografii, geografii i historii literatury wybranych obszarów Wschodu. Studenci mieli też wybrać jeden $\mathrm{z}$ trzech kierunków specjalizacji: historyczny, językoznawczy lub literaturoznawczy. W celu uzyskania tytułu magistra student oprócz napisania pracy musiał również podjąć dyskusję na jej temat $\mathrm{z}$ komisją egzaminacyjną, a dodatkowo kontrolowana była jego wiedza $\mathrm{z}$ danej dziedziny oraz znajomość zagadnień związanych z wybranym językiem głównym ${ }^{61}$.

Praktyczna realizacja wytycznych ministerstwa zależała od możliwości danego ośrodka naukowego. Student we Lwowie miał do dyspozycji sześć grup: arabsko-turecko-perską (filologia Wschodu muzułmańskiego), arabsko-hebrajsko-aramejską (semitologia), indyjsko-arabską, indyjsko-irańską, mongolsko-turecką (ałtaistyka) oraz mongolsko-indyjską ${ }^{62}$. Niestety nie dotarłam do informacji, ile takich grup było w Krakowie.

Po II wojnie światowej Wydział Teologiczny składał się z 12 zakładów naukowych. Katedrę Pisma Świętego Starego Testamentu objął biblista i orientalista,

58 AN PAU/PAN w Kr, K III-7, 13, M. Lewicki, Historia orientalistyki w Polsce odrodzonej, [b.d.],

k. 147; Spis wykladów rok akademicki 1925/1926, Kraków 1926, [b.n.s.].

59 W. Zajączkowski, op. cit., s. 379.

60 AN PAU/PAN Kr, K III-7, 13; M. Lewicki, Historia orientalistyki w Polsce odrodzonej, [b.d.], k. 6. Najprawdopodobniej chodzi o rozporządzenie MWRiOP o programie studiów i egzaminach w zakresie filologii orientalnej na stopień magistra, ponieważ w okresie 1926-1928 wydano rozporządzenia dla poszczególnych dyscyplin w ramach studiów kończących się uzyskaniem stopnia magistra filozofii.

${ }_{61}$ AN PAU/PAN w Kr, K III-7, 13, M. Lewicki, Historia orientalistyki w Polsce odrodzonej, [b.d.], k. 141.

62 Ibidem, k. 142. 
ksiądz Aleksy Klawek ${ }^{63}$. Przed wojną był profesorem, kierownikiem katedry Starego Testamentu i dziekanem Wydziału Teologicznego na Uniwersytecie Jana Kazimierza we Lwowie ${ }^{64}$. Jego zainteresowania badawcze oscylowały wokół biblistyki Starego i Nowego Testamentu, etymologii, orientalistyki i historii starożytnego Bliskiego Wschodu. W 1954 roku Wydział Teologiczny UJ został przeniesiony do Akademii Teologii Katolickiej w Warszawie ${ }^{65}$. Był to zarazem koniec wykładania języków wschodnich w ramach studiów teologicznych na UJ. Po wojnie ponownie zaczęła funkcjonować orientalistyka w Krakowie i Warszawie, dla Lwowa koniec wojny był również końcem polskiej orientalistyki, ponieważ miasto przestało znajdować się w granicach Polski.

\section{PODSUMOWANIE}

W XIX wieku języków orientalnych nauczano na wydziałach teologii w Krakowie i we Lwowie. W okresie 1803-1809 nastąpiło połączenie uczelni, co pozwoliło stworzyć lepszą kadrę w zunifikowanym ośrodku. Był to jednak stan krótkotrwały. Na początku XX wieku utworzono orientalistykę zarówno w Krakowie (1919), jak i we Lwowie (1921). Warszawa dołączyła do tego grona dopiero w 1932 roku. Nie znaczy to, że zarówno na UJ, jak i na Uniwersytecie Jana Kazimierza już wcześniej nie podejmowano prób utworzenia katedr, które zajmowały się badaniem i nauczaniem języków Wschodu. Ich funkcjonowanie okazywało się jednak zazwyczaj krótkotrwałe i częstokroć związane z konkretnym wykładowcą.

Wybitne postacie polskiej orientalistyki, takie jak Andrzej Gawroński, Franciszek Machalski czy Tadeusz Lewicki, zazwyczaj związane były zarówno z krakowską, jak i lwowską wszechnicą. Czasami rozpoczynali oni drogę naukową w Krakowie i później przenosili się na inne uczelnie, innym razem po odebraniu edukacji i osiągnięciu pozycji naukowej zasilali krakowski uniwersytet. Często byli niezastąpieni i po ich odejściu dana katedra przestawała funkcjonować. Za przykład może posłużyć Andrzej Gawroński, który habilitację i profesurę uzyskał na UJ, tam również objął katedrę sanskrytu, ale po jego przenosinach do Lwowa wspomniana katedra przez kilka lat pozostawała nieobsadzona.

Analizując rozwój krakowskiej i lwowskiej orientalistyki, można byłoby dojść do wniosku, że w Krakowie prężniej działały nauki związane z Bliskim Wschodem (głównie za sprawą Tadeusza Kowalskiego), we Lwowie zaś - z Dalekim Wschodem (duży wkład mieli w tym zakresie Andrzej Gawroński czy Władysław Kotwicz).

\footnotetext{
${ }_{63}$ Kronika Uniwersytetu Jagiellońskiego za lata akademickie 1945/1946-1955/1956, Kraków 1971, s. 55.

${ }^{64}$ J. Draus, Uniwersytet Jana Kazimierza we Lwowie 1918-1946. Portret kresowej uczelni, Kraków 2007, s. 39.

${ }_{65}$ Wydział Teologiczny został na podstawie uchwały Rady Ministrów z 11 VIII 1954 r. wcielony do nowo utworzonej Akademii Teologii Katolickiej w Warszawie. Kronika Uniwersytetu Jagiellońskiego..., s. 55.
} 
Sytuacja była jednak bardziej skomplikowana i płynna, zależna od stanu kadry w danym momencie. Słuszność mógł mieć Władysław Kotwicz, zwolennik centralizacji orientalistyk, gdy twierdził, że przy połączeniu polskich orientalistyk w jednym ośrodku studia zyskałyby wybitnych specjalistów zajmujących się wieloma dziedzinami w jednym miejscu. Tymczasem właśnie partykularne problemy budżetowo-kadrowe powodowały rozmaite problemy organizacyjne, między innymi zamknięcie sinologii czy katedry języków semickich we Lwowie, kiedy to wykładowcy przenieśli się do Warszawy.

Obydwie uczelnie miały problemy kadrowe, ale mimo to zatrudniały wybitnych specjalistów. II wojna światowa oraz zmiana granic doprowadziły do opuszczenia Lwowa przez znaczą część kadry naukowej i zasilenia ośrodków w Krakowie i Warszawie. Byli to bardzo znamienici wykładowcy, którzy przyczynili się do wykształcenia kolejnych pokoleń polskich orientalistów. Powiązania między jednostkami i badaczami miały jednak zwykle charakter personalny, orientaliści z uwagi na niewielkie środowisko znali się, utrzymywali ze sobą kontakty i dzielili się wynikami swoich badań. Bardzo istotne dla wymiany doświadczeń były pierwsze naukowe czasopisma orientalistyczne jak Przegląd Orientalistyczny, brakowało jednak inicjatyw na poziomie uniwersytetów.

\section{BIBLIOGRAFIA}

\section{Źródła archiwalne}

Archiwum Nauki Polskiej Akademii Umiejętności i Polskiej Akademii Nauk w Krakowie

Spuścizna Ireny i Mariana Lewickich - K III-7.

Archiwum Uniwersytetu Jagiellońskiego

Wydział Filozoficzny - Teczki akt habilitacyjnych - WF II 121.

Wydział Filologiczny - Wnioski o nadanie tytułu profesora 1954-1972, cz. II - WFlg.

\section{Źródła drukowane}

Długosz J., Roczniki czyli kroniki sławnego Królestwa Polskiego, t. VII, ks. XI, Warszawa 2009.

Kronika Uniwersytetu Jagiellońskiego za lata akademickie 1945/1946-1955/1956, Kraków 1971.

Personal-Stand und Ordnung der Vorlesungen an der k.k. Jagellonischen Universität zu Krakau im Sommer-Semester des Schuljahres 1859, Krakau 1859.

Personal-Stand und Ordnung der Vorlesungen an der k. k. Jagellonischen Universität zu Krakau im Sommer-Semester des Schuljahres 1860, Krakau 1860. 
Sktad uniwersytetu rok szkolny 1921/1922, Kraków 1922.

Spis wykładów w pótroczu letnem rok szkolny 1916/1917, Kraków 1917.

Spis wykładów rok akademicki 1925/1926, Kraków 1926.

\section{Literatura przedmiotu}

Banach A.K., Czasy zaborów. Uniwersytet Jagielloński w latach 1795-1918 [w:] Dzieje Uniwersytetu Jagiellońskiego, red. K. Stopka, A.K. Banach, J. Dybiec, Kraków 2000.

Barycz H., Historja Uniwersytetu Jagiellońskiego w epoce humanizmu, Kraków 1935.

Chwalba A., Historia Polski 1795-1918, Kraków 2000.

Czekalska R., Helena Willman-Grabowska [w:] Uniwersytet Jagielloński. Złota Ksiega Wydziału Filologicznego, red. J. Michalik, W. Walecki, Kraków 2000.

Kałużyński S., Władysław Kotwicz w stulecie urodzin, „Przegląd Orientalistyczny” 1972, nr 2 (82).

Krasnowolska A., Iranistyka krakowska i jej twórcy [w:] Orientalia Commemoriativa, red. L. Sudyk, Kraków 2011.

Kraus J., Uniwersytet Jana Kazimierza we Lwowie 1918-1946. Portret kresowej uczelni, Kraków 2007.

Krowicki S.L., Polska Szkoła Języków Orientalnych w Stambule, „Przegląd Historyczno-Oświatowy" 2011, nr 3-4.

Kubiak W., Profesor Tadeusz Lewicki: January 28, 1906-November 22, 1992, „Rocznik Orientalistyczny" 1997, t. II.

Mańkowski T., Orient w polskiej kulturze artystycznej, Wrocław 1959.

Michalewska K., Z dziejów nauczenia orientalistyki na Uniwersytecie Jagiellońskim w latach 1818-1836 [w:] Szkice z dziejów polskiej orientalistyki, t. II, red. M. Lewicki, Wrocław 1966.

Nykiel P., Türk atları Vistül nehrinden su içtiğinde / Kiedy Turcy napoja konie w Wiśle / When the Turks Water Their Horses in Vistula, Warszawa 2016.

Redzik A., Uniwersytet Józefiński 1784-1805 [w:] Academia Militans. Uniwersytet Jana Kazimierza we Lwowie, red. A. Redzik, Kraków 2015.

Reychman J., Historia Turcji, Wrocław 1973.

Reychman J., Polska Szkoła Orjentalna w Stambule za Stanisława Augusta, „Wschód. Kwartalnik Poświęcony Sprawom Wschodu” 1930, nr 1.

Richter B., Michat Boim 1612-1659, „Rocznik Orientalistyczny” 1926, t. IV.

Siemieniec-Gołaś E., Krakowska turkologia - historia, teraźniejszość i perspektywy [w:] Orientalia Commemoriativa, red. L. Sudyk, Kraków 2011.

Sierakowska-Dyndo J., Surdykowski S., Iranistyka [w:] 75 lat Instytutu Orientalistyki Uniwersytetu Warszawskiego, red. M. Popke, Warszawa 2007.

Skubała-Tokarska Z., Tokarski Z., Uniwersytety w Polsce. Rys historyczny, Warszawa 1972.

Słuszkiewicz E., Wspomnienie o Andrzeju Gawrońskim w dziesięciolecie zgonu, „Rocznik Oryentalistyczny" 1936, t. XII.

Sroka Ł.T., Wydziat Humanistyczny [w:] Academia Militans. Uniwersytet Jana Kazimierza we Lwowie, red. A. Redzik, Kraków 2015. 
Zaborski A., Tadeusz Kowalski - pierwszy i ostatni nowoczesny orientalista polski [w:] Tadeusz Kowalski 1889-1948. Materiaty z Posiedzenia Naukowego PAU w dniu 19 czerwca 1998 r., red. R. Majkowska, Kraków 1999.

Zajączkowski W., Z dziejów orientalistyki na Uniwersytecie Jagiellońskim [w:] Wydziat Filologiczny Uniwersytetu Jagiellońskiego. Historia katedr, red. W. Taszycki, A. Zaręba, Kraków 1964.

\section{Czasopisma}

Fedirko J., Fenomenalny multilingwista. Profesor Andrzej Gawroński (1885-1927), „Alma Mater" 2008, nr 2 (100).

Maciuszak K., Z historii orientalistyki na Uniwersytecie Jagiellońskim, „Alma Mater” 2009/2010, nr 120-121.

\section{Źródła internetowe}

Krasnowolska A., Machalski Franciszek [w:] Encyclopaedia Iranica, http://www.iranicaonline.org/articles/machalski-franciszek [dostęp: 10.08.2017].

Polskie Towarzystwo Orientalistyczne. Historia i cele, http://pto.orient.uw.edu.pl/ [dostęp: 10.08.2017]. 